УДК $615.11: 615.322: 582.794 .1$

DOI https://doi.org/10.11603/2312-0967.2019.2.10193

\title{
ДОСЛІДЖЕННЯ АНАТОМІЧНИХ ОЗНАК ПЛОДІВ МОРКВИ ДИКОЇ ТА МОРКВИ ПОСІВної
}

\author{
О. А. Кисличенко ${ }^{1}$, О. О. Соколова ${ }^{2}$, А. Г. Котов ${ }^{2}$ В. В. Процька ${ }^{1}$, І. О. Журавель ${ }^{1}$, \\ Е. Е. Котова ${ }^{2}$ \\ Національний фрармацевтичний університет ${ }^{1}$, Харків \\ Державне підприємство «Український науковий фармакопейний чентр якості \\ лікарських засобів»² \\ vvprotskaya@gmail.com
}

\section{ІНФОРМАЦІЯ}

Надійшла до редакції / Received 28.05.2019

Після доопрацювання / Revised: 31.05.2019

Прийнято до друку / Accepted: 03.06.2019

\section{Ключові слова:}

морква дика;

морква посівна;

плоди,

анатомічна будова;

ДФУ.

\section{АНОТАЦІЯ}

Мета роботи. Дослідження анатомічної будови та встановлення основних діагностичних ознак шліфованих та нешліфованих плодів моркви дикої та моркви посівної.

Матеріали і методи. Досліджували 10 серій нешліфованих плодів моркви дикої та моркви посівної, а також 5 серій шліфованих плодів моркви посівної. Мікропрепарати готували відповідно до загальних правил.

Результати й обговорення. Як основні анатомічні діагностичні ознаки нешліфованих плодів моркви дикої та моркви посівної обрано наявність чотирьох виступаючих ребер на опуклому та двох на внутрішньому боці мерикарпію, простих одноклітинних волосків із бородавчастою поверхнею. На мікропрепаратах шліфованих плодів моркви посівної виявлено фрагменти цих структур, що може бути пов'язано з особливостями їх заготівлі. Спільними діагностичними ознаками для усіх зразків було наявність чотирьох округлотрикутних канальців в головних ребрах і двох овальних на увігнутій стороні мерикарпію, наявність в ендоспермі клітин з алейроновими зернами, друзами та поодинокими кристалами кальцію оксалату.

Висновки. Результати дослідження анатомічної будови плодів моркви дикої та моркви посівної використані при розробці проекту розділу «дентифрікація В» національної частини монограсії «Моркви дикої плодиN․
Вступ. За даними літератури рід Морква (Daucus L.) належить до родини Селерові (Apiaceae L.) і нараховує 20-25 видів [1-8]. Результати генетичних аналізів американських дослідників свідчать, що обидві рослини мають близьку генетичну структуру і підтверджують, що морква посівна (Daucus carota subsp. sativus (Hoffm.) Arcang.) є підвидом моркви дикої (Daucus carota L.) [3, 6, 7]. Однак попри генетичну спорідненість, плоди цих рослин мають деякі морфолого-анатомічні відмінності, а саме відсутність шипів та опушення у плодів моркви посівної. Раніше пові- домлялось, що спеціалісти Інституту ботаніки НАН України ім. М. Г. Холодного пояснили таку різницю шліфруванням - обов'язковою обробкою при заготівлі цього виду сировини [9].

В індійській народній медицині екстракти 3 плодів моркви дикої використовували для регуляції менструального циклу [2]. Іранські вчені встановили, що метанольні екстракти плодів моркви посівної проявляли гіпоглікемічну, антидіабетичну, сечогінну, антиноцицептивну, антибактеріальну та антиоксидантну активності [4, 7]. Індійські вчені стверджують, що екстракти плодів

ISSN 2312-0967. Фармацевтичний часопис. 2019. № 2 
моркви дикої у дослідах на щурах сприяли зниженню рівня холестерину в крові, проявляли спазмолітичний, протизапальний, знеболювальний, кардіо- та гепатопротекторний ефекти [8]. В ході експериментів на щурах пакистанські вчені встановили, що метанольні екстракти плодів моркви дикої у дозі 10 мг/кг сприяють нормалізації артеріального тиску у піддослідних тварин [10].

На сьогодні монограсрія на плоди моркви дикої входить до Фармакопеї Народної Республіки Китай [5]. Крім того, до Британської трав'яної фрармакопеї входить трава моркви дикої [11]. В Україні плоди моркви дикої та моркви посівної є неофіцинальною сировиною, а єдиним нормативним документом, що регламентує якість плодів моркви дикої, є тимчасова ФС 42-2817-91 [9]. Проте методи аналізу, запропоновані у цьому документі, застарілі. Тому на сьогодні виникає потреба розробки монографії до ДФУ на запропоновані види сировини. Для цього, відповідно, необхідно провести комплексне фрармакогностичне дослідження плодів моркви дикої та моркви посівної на сучасному науковому рівні, включно вивчення анатомічної будови.

Мета роботи - дослідження анатомічної будови, встановлення основних діагностичних ознак шліфрованих та нешліфованих плодів моркви дикої та моркви посівної для розробки розділу «Ідентифрікація В» проекту Національної монографії ДФУ «Моркви дикої плоди ${ }^{\mathrm{N}}$.

Матеріали і методи. Для дослідження мікроскопічної будови використовували 10 серій шліфованих та нешліфованих плодів моркви посівної, а також 5 серій нешліфованих плодів моркви дикої, які були заготовлені самостійно на території Харківської, Сумської, Полтавської, Хмельницької, Одеської та Житомирської областей, а також сировину промислового виробництва ПАТ «Галичсрарм» (м. Львів).

Мікропрепарати для дослідження готували із фріксованих у суміші етанол-гліцерин-вода (1:1:1) шліфованих та нешліфованих плодів моркви посівної та нешліфованих плодів моркви дикої. Мікропрепарати готували за загальними правилами. Анатомічні ознаки сировини ви- вчали за допомогою мікроскопів «Ломо Мікмед-1» та «Granum» при збільшенні у 40-100 разів. Результати дослідження фротограсрували за допомогою камери «Digital camera for microscope DCM 300».

Результати й обговорення. За анатомічною будовою усі досліджувані серії плодів моркви дикої та моркви посівної відрізнялись незначно.

На поперечному перерізі плоди моркви дикої та моркви посівної мали трапецієподібну форму зі злегка увігнутим всередину абаксіальним боком. На зовнішньому опуклому боці нешліфованих плодів моркви дикої та моркви посівної проглядались чотири головні ребра з багатоклітинними шипами. В той же час, таких утворень не виявлено у зразках шліфованих плодів моркви посівної. Поперечні перерізи нешліфрованих (рис. 1А) та шліфованих (рис. 1Б) плодів моркви зображено на рисунку 1.

Анатомічну будову шипів на великих ребрах нешліфрованих плодів моркви дикої та моркви посівної зображено на рисунку 2.

На увігнутому боці мерикарпію нешліфованих плодів моркви дикої та моркви посівної знаходились два малі ребра, які вкриті простими одноклітинними товстостінними волосками 3 дещо бородавчастою поверхнею (рис. 3). На мікропрепаратах шліфованих плодів моркви посівної, у свою чергу, було виявлено лише фррагменти таких волосків.

Перикарп складався 3 майже ізодіаметричних клітин паренхіми з прямими тонкими стінками та дрібних тангентально витягнутих клітин склеренхіми. Як видно на рисунку 3 , на головних ребрах розташовувались великі схізогенні внутрішні канальці, а між ребрами провідні пучки закритого колатерального типу.

Канальці, які знаходились в ребрах на опуклому боці мерикарпію, мали овально-трикутну фрорму (рис. 3).

Два великі зближені улоговинні канальці з темнобурими вистилаючими клітинами, що розташовуються в ребрах абаксіального боку, мали овальну фрорму (рис. 4).

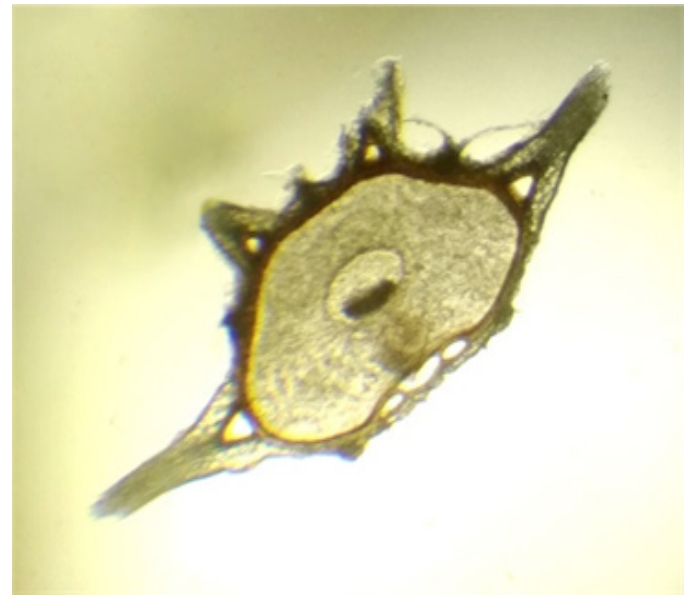

A

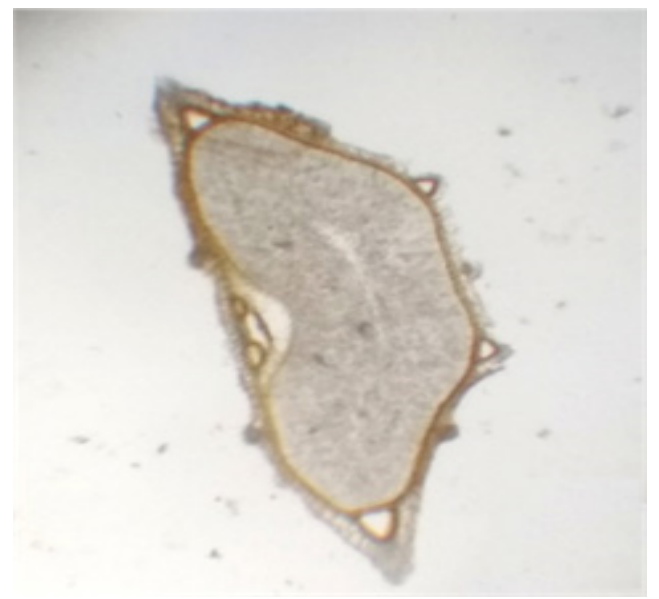

Б

Рис. 1. Поперечний переріз нешліфованих (A) та шліфованих плодів моркви (збільшення ×10).

ISSN 2312-0967. Pharmaceutical review. 2019. № 2 


\section{PHARMACEUTICAL \\ BOTANYPHARMACEUTICAL BOTANY}

Фармацевтична ботаніка

Phytochemical botany

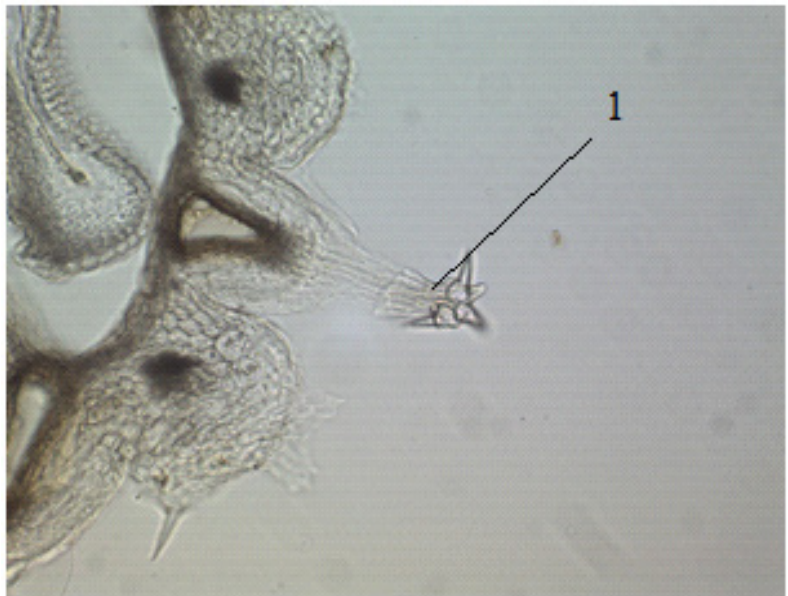

A

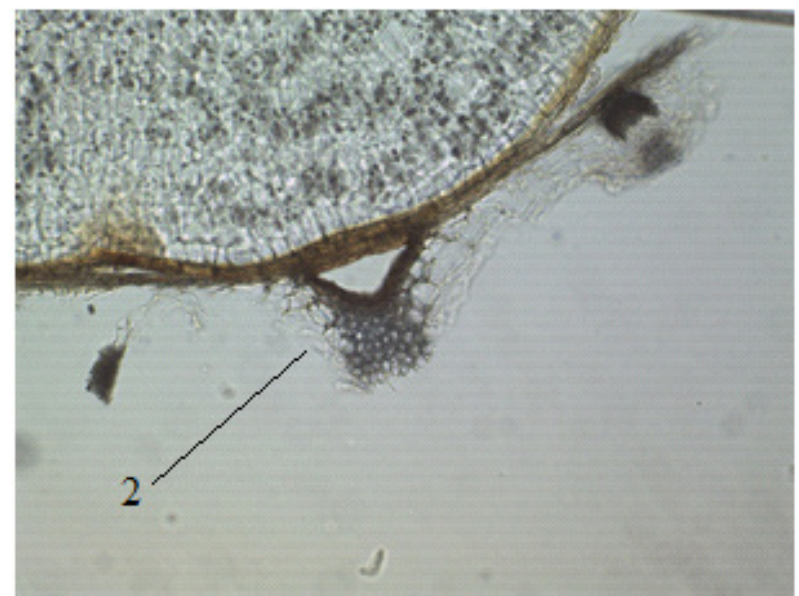

Б

Рис. 2. Поперечний переріз нешліфованих (А) та шліфованих (Б) плодів моркви (збільшення ×40): 1 - шипи на великих ребрах; 2 - залишки шипа.

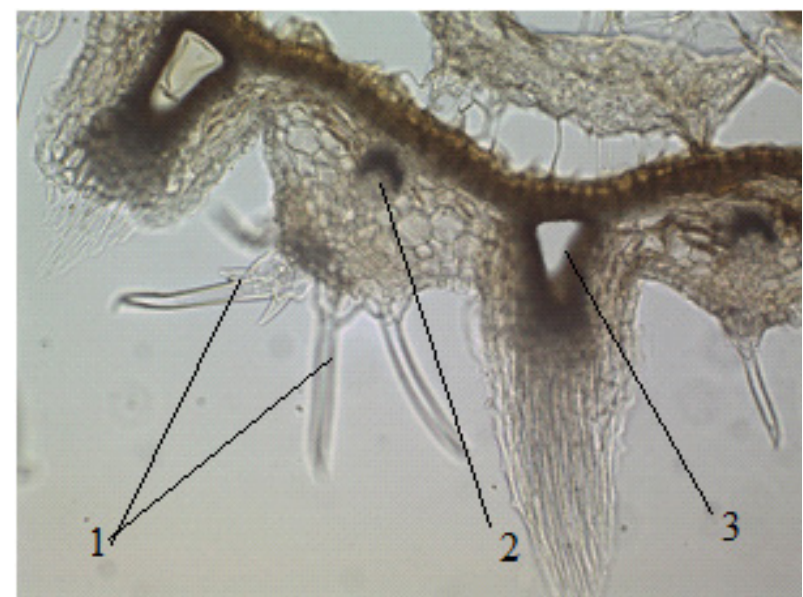

Рис. 3. Поперечний переріз плодів моркви (збільшення х40): 1 - одноклітинні волоски на малому ребрі мерикарпіїв; 2 - провідний пучок закритого колатерального типу; 3 - схізогенні внутрішні канальці овальнотрикутної фрорми.

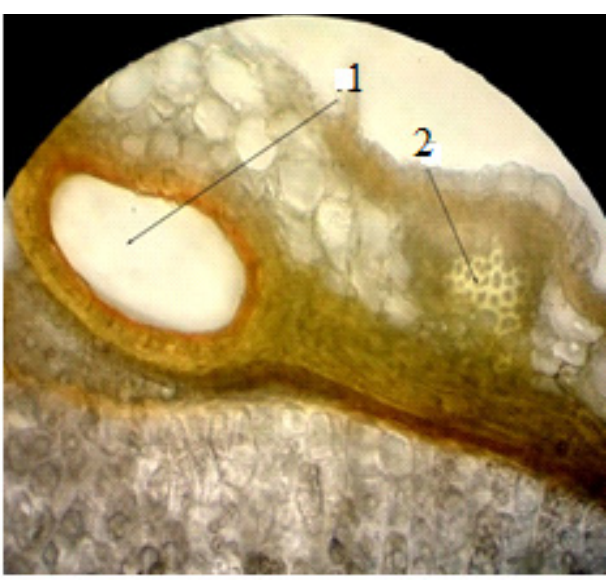

A

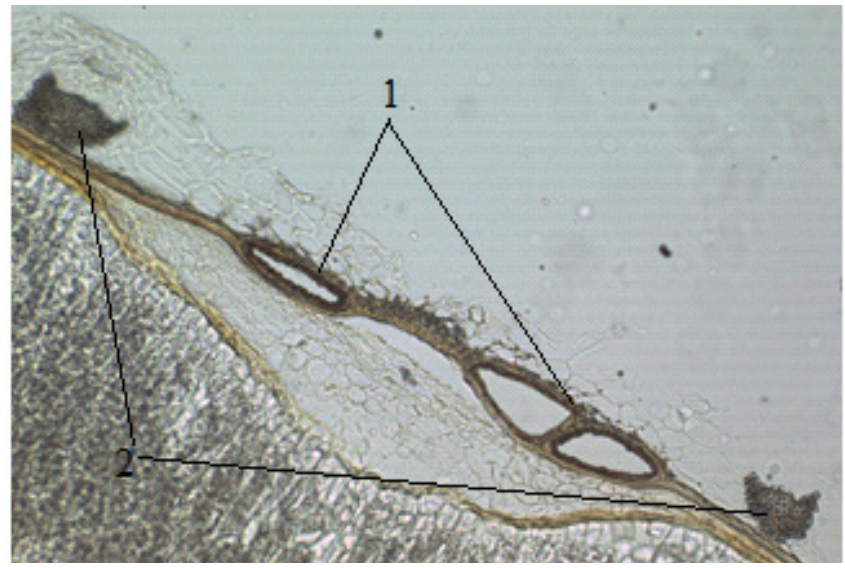

Б

Рис. 4. Поперечний переріз плодів моркви (збільшення $\times 100(A)$ та збільшення $\times 40$ (Б)): 1 - зближені внутрішні канальці на увігнутому боці плода; 2 - провідні пучки.

ISSN 2312-0967. Фармацевтичний часопис. 2019. № 2 
Структура мезокарпу представлена великими паренхіматозними клітинами 3 тонкими стінками. Клітини ендосперму заповнені алейроновими зернами та краплями жирної олії (рис. 5). Крім того, зустрічаються друзи і поодинокі кристали кальцію оксалату.

Ендокарп складався 3 дрібних тангентально витягнутих клітин з прямими, злегка звивистими стінками. Інтегумент зародка одношаровий, був утворений дрібними сильно витягненими, майже сплющеними клітинами, що щільно прилягали одна до одної. Зародок мав еліпсоїдну фрорму, утворений дрібними тонкостінними клітинами.

У подальшому було проаналізовано вимоги існуючої нормативної документації, яка регламентує якість плодів моркви дикої, встановлено відповідність досліджуваних серій цим вимогам. Відповідність шліфрованих та нешліфованих плодів моркви дикої та моркви посівної вимогам тимчасової ФС 42-2817- 91 представлено в таблиці 1.

За результатами порівняльного аналізу можна зробити висновок, що нешліфовані плоди моркви дикої та моркви посівної мали ідентичну анатомічну будову і повністю відповідали вимогам тимчасової ФС 42-2817-91. Шліфовані плоди моркви посівної частково відповідали цим вимогам, оскільки на мікропрепаратах цього виду сировини виявлено лише фррагменти шипів та волосків. Цей фракт можна пояснити особливістю заготівлі даної сировини, а саме процесом шліфування.

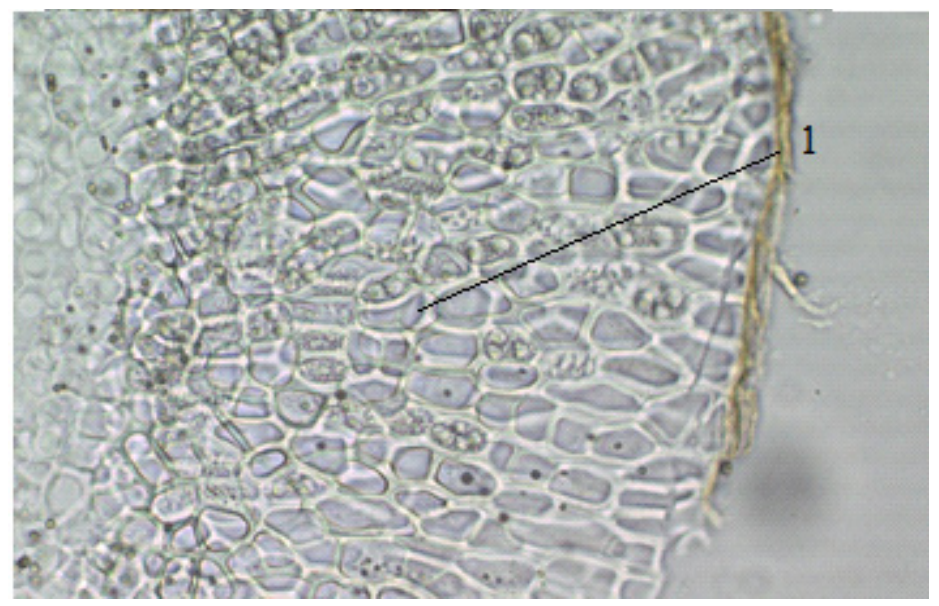

Рис. 5. Поперечний переріз плодів моркви (збільшення ×100): 1 - ендосперм з алейроновими зернами та краплями жирної олії.

Таблиця 1

Відповідність анатомічних ознак плодів моркви дикої та моркви посівної вимогам тимчасової ФС 42-2817-91

\begin{tabular}{|c|c|c|c|}
\hline $\begin{array}{c}\text { Вимоги ФС 42-2817-91 щодо } \\
\text { анатомічних ознак моркви дикої }\end{array}$ & $\begin{array}{l}\text { Нешлісровані плоди } \\
\text { моркви дикої }\end{array}$ & $\begin{array}{l}\text { Нешлісровані плоди } \\
\text { моркви посівної }\end{array}$ & $\begin{array}{c}\text { Шліфровані плоди моркви } \\
\text { посівної }\end{array}$ \\
\hline $\begin{array}{l}\text { Тонкостінна паренхіма зовнішньої } \\
\text { частини і склеренхіма із тангентально } \\
\text { витягнутих дрібних клітин внутрішньої } \\
\text { частини мерикарпіїв }\end{array}$ & Відповідає & Відповідає & Відповідає \\
\hline $\begin{array}{l}\text { Багатоклітинні шипи на ребрах } \\
\text { мерикарпіїв }\end{array}$ & Відповідає & Відповідає & Обламані (не відповідає) \\
\hline $\begin{array}{l}\text { Прості, одноклітинні, товстостінні } \\
\text { волоски } 3 \text { дещо бородавчастою } \\
\text { поверхнею }\end{array}$ & Відповідає & Відповідає & Обламані (не відповідає) \\
\hline $\begin{array}{l}\text { Чотири великі округло-трикутні } \\
\text { канальці в головних реберцях і два } \\
\text { великі овальні, зближені улоговинні } \\
\text { канальці на черевній стороні з темно- } \\
\text { бурими вистилаючими клітинами }\end{array}$ & Відповідає & Відповідає & Відповідає \\
\hline $\begin{array}{l}\text { Ендосперм із тонкостінних клітин, } \\
\text { заповнених жирною олією та } \\
\text { дрібними алейроновими зернами }\end{array}$ & Відповідає & Відповідає & Відповідає \\
\hline $\begin{array}{l}\text { Зустрічаються друзи і поодинокі } \\
\text { кристали кальцію оксалату }\end{array}$ & Відповідає & Відповідає & Відповідає \\
\hline
\end{tabular}

ISSN 2312-0967. Pharmaceutical review. 2019. № 2 
Фармацевтична ботаніка

Phytochemical botany

Висновки. Досліджено анатомічну будову 15 серій шліфованих та нешліфованих плодів моркви дикої та моркви посівної. Встановлено, що за мікроскопічними ознаками плоди моркви дикої та моркви посівної відрізняються незначно.

Встановлено основні анатомічні діагностичні ознаки шліфованих та нешліфованих плодів моркви дикої та моркви посівної. До таких ознак віднесено наявність чотирьох виступаючих ребер на адаксиальному та двох на внутрішньому боці мерикарпію, а також простих одноклітинних волосків із бородавчатою поверхнею у нешліфованих плодів та фррагменти цих структур у шліфованих плодів. Крім того, спільними діагностичними ознаками усіх досліджуваних серій було наявність чотирьох округло-трикутних канальців у головних ребрах і двох овальних на увігнутому боці мерикарпію, наявність в ендоспермі клітин 3 алейроновими зернами, друзами та поодинокими кристалами кальцію оксалату.

Встановлено відповідність анатомічних ознак нешліфрованих плодів моркви дикої та моркви посівної, а також шліфованих плодів моркви посівної вимогам існуючих документів, що регламентують їх якість. Встановлено, що нешліфовані плоди моркви дикої та моркви посівної повністю відповідають вимогам тимчасової ФС 42-2817-91, шліфровані плоди моркви посівної - частково відповідають.

Результати дослідження анатомічної будови плодів моркви дикої та моркви посівної використані при розробці проекту розділу «Ідентифікація В» Національної монограсрії «Моркви дикої плоди ${ }^{N} »$.

Конфлікт інтересів: відсутній.

Conflicts of interest: authors have no conflict of interest to declare.

\title{
ИССЛЕДОВАНИЕ АНАТОМИЧЕСКИХ ПРИЗНАКОВ ПЛОДОВ МОРКОВИ ДИКОЙ И МОРКОВИ ПОСЕВНОЙ
}

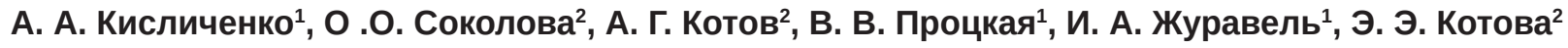 \\ Национальный фрармацевтический университет¹, Харьков \\ Государственное предприятие «Украинский научный фрармакопейный чентр качества \\ лекарственных средств»² \\ vvprotskaya@gmail.com
}

Цель работы. Исследование анатомического строения и определение основных диагностических признаков шлифрованных и нешлифованных плодов моркови дикой и моркови посевной.

Материалы и методы. Исследовали 10 серий нешлифованных плодов моркови дикой и моркови посевной, а также 5 серий шлифрованных плодов моркови посевной. Микропрепараты готовили согласно общих правил.

Результаты и обсуждение. В качестве основных анатомических диагностических признаков плодов моркови дикой и моркови посевной были выбраны наличие четырех выступающих ребер на выпуклой и двух на внутренней стороне мерикарпия, простых одноклеточных волосков с бородавчатой поверхностью. На микропрепаратах шлифованных плодов моркови посевной обнаружены фррагменты этих структур, что может быть связано с особенностями их обработки. Общими диагностическими признаками для всех образцов были наличие четырех округло-треугольных канальцев в главных ребрах и двух овальных на вогнутой стороне мерикарпия, наличие в эндосперме клеток с алейроновыми зернами, друзами и одиночными кристаллами кальция оксалата.

Выводы. Результаты исследования анатомического строения плодов моркови дикой и моркови посевной использованы при разработке проекта раздела «Идентисрикация В» национальной части монограсрии «Моркови дикой плоды ${ }^{\mathrm{\nu}}$.

Ключевые слова: морковь дикая; морковь посевная; плоды; анатомическое строение; ГФУ.

\section{THE STUDY OF ANATOMIC FEATURES OF DAUCUS CAROTA AND DAUCUS CAROTA SUBSP. SATIVUS}

\author{
O. A. Kyslychenko ${ }^{1}$, O. O. Sokolova ${ }^{2}$, A. G. Kotov², V. V. Protska ${ }^{1}$, I. O. Zhuravel ${ }^{1}$, E. E. Kotova ${ }^{2}$ \\ National University of Pharmacy ${ }^{1}$, Kharkiv \\ State Enterprise "Ukrainian Scientific Pharmacopoeial Center for Quality of Medicines"2 \\ vvprotskaya@gmail.com
}

The aim of the work. Research of the anatomical structure and establishment of the main diagnostic features of polished and non-polished Daucus carota L. fruits and Daucus carota subsp. sativus (Hoffm.) Arcang. fruits.

Materials and Methods. 10 series of polished Daucus carota L. fruits and Daucus carota subsp. sativus (Hoffm.) Arcang. fruits and 5 series of unpolished of Daucus carota L. fruits were studied. Microslides were prepared in accordance with the general rules.

ISSN 2312-0967. Фармацевтичний часопис. 2019. № 2 
Results and Discussion. The four protruding edges on the convex and two on the inner side of mericarp, simple unicellular hairs with a warty surface were chosen as the main anatomical diagnostic features of the unpolished fruit of Daucus carota L. and Daucus carota subsp. sativus (Hoffm.) Arcang. fruits. On microslides of Daucus carota subsp. sativus (Hoffm.) Arcang. polished fruits. The fragments of these structures were discovered, which may be due to the features of their harvesting. The presence of four round-triangular tubules in the major edges and two ovals on the concave side of the mericarp, the presence of cells with aleuroneous grains, druses and single crystals of calcium oxalate in the endosperm were the common diagnostic features for all specimens.

Conclusions. The results of the study of the anatomical structure of Daucus carota L. fruits and Daucus carota subsp. sativus (Hoffm.) Arcang. fruits were used in the design of the "Identification B" section of the national part of the "Daucus carota fruits" monograph.

Key words: Daucus carota; Daucus carota subsp.; sativus; fruits; anatomical structure; SPhU.

\section{Список літератури}

1. A new sesquiterpene from the fruits of Daucus carota $L$. / Hong-Wei Fu, Lin Zhang, Tao Yi, Jing-Kui Tian // Molecules. - 2009. - No. 14 (8). - P. 2862-2867. - URL : https://doi.org/10.3390/molecules14082862

2. Jansen G. C. Carrot seed for contraception: a review/ G. C. Jansen, H. Wohlmuth // Australian Journal of Herbal Medicine. -2014. - No. 26 (1). - P. 10-17. - URL: https://www.researchgate.net/publication/289343049_ Carrot seed for contraception A review

3. Multivariate analysis of morphological diversity among closely related Daucus species and subspecies in Tunisia / N. Mezghani, J. B. Amor, D. M. Spooner [et al.] // Genet. Resour. Crop Evol. - 2017. - No. 64. - P. 21452159. - URL : https://doi.org/10.1007/s10722-0170505-5

4. Özcan Mehmet Musa. Chemical composition of carrot seeds (Daucus carota L.) cultivated in Turkey: characterization of the seed oil and essential oil / Özcan Mehmet Musa, Chalchat Jean Claude // Grasas y Aceites. - 2007. - No. 58 (4). - P. 359-365. - URL : https://doi.org/10.3989/gya.2007.v58.i4.447

5. Pharmacopea of the People's Republic of China / People's Medical Publishing House. Edition 1st. - Ovid: People's Medical Publishing House, 2005. - P. 946.

6. Phylogenomics of the Carrot genus (Daucus, Apiaceae) / C. Arbizu, H. Ruess, D. Senalik, P. W. Simon [et al.] // American Journal of Botany. - 2014. - No. 101 (10). - P. 1666-1685. - URL : https://doi.org/10.3732/ ajb.1400106

\section{References}

1. Hong-Wei Fu, Lin Zhang, Tao Yi, Jing-Kui Tian (2009). A new sesquiterpene from the fruits of Daucus carota $L$. Molecules, 2009;14: 2862-7.

2. Jansen GC, Wohlmuth H. (2014). Carrot seed for contraception: a review. Australian Journal of Herbal Medicine. 2014;26(1): 10-7. Available from: https://www.researchgate.net/publication/289343049_Carrot_seed_ for_contraception_A_review

3. Mezghani N, Amor JB, Spooner DM, Simon PW, Mezghani N, Boubaker $\mathrm{H}$ et al. Multivariate analysis of morphological diversity among closely related Daucus species and subspecies in Tunisia. Genet. Resour Crop
7. Pouraboli Iran. The effect of Daucus carota seeds extract on lipid profile, LFT and kidney function indicators in streptozocin-induced diabetic rats / Pouraboli Iran, Ranjbar Banafshe // International Journal of Plant Science and Ecology. - 2015. - Vol. 1, No. 3 - P. 84 87. - URL : http://files.aiscience.org/journal/article/ pdf/70060055.pdf

8. Therapeutic uses of Daucus carota: A Review / B. Mahammad Shakheel, Tripthi Saliyan, Satish S, Karunakar Hedge // International Journal of Pharma And Chemical Research. - 2017. - Vol. 3, Iss. 2. - P. 138-43. - URL : https://pdfs.semanticscholar.org/527f/20adbacecdd357 036c5d069be30ee42b9f30.pdf

9. Фармакопейна стандартизація плодів Daucus Carota L. за макроскопічними ознаками / E. E. Котова, О. Г. Вовк, О. А. Кисличенко [ та ін.] // Теоретичні та практичні аспекти дослідження лікарських рослин : матеріали III міжнар. наук.-практ. internetконор., м. Харків, 26-28 листоп. 2018 р. - Х. : НФаУ, 2018. - C. 116-117. http://dspace.nuph.edu.ua/handle/123456789/18288

10. Hypotensive action of coumarin glycosides from Daucus carota / A. H. Gilani, F. Shaheen, S. A Saeed [et al.] // Phytomedicine. - 2000. - Vol. 7, Iss. 5. P. 423-426. - URL : https://doi.org/10.1016/S09447113(00)80064-1

11. British Herbal Pharmacopea / British Herbal Medicine Association. - Bournemouth, United Kingdom, British Herbal Medicine Association, 1996. - 212 p.

Evol. 2017;64: 2145-59. Available from: https://doi. org/10.1007/s10722-017-0505-5

4. Özcan Mehmet Musa, Chalchat Jean Claude. Chemical composition of carrot seeds (Daucus carota L.) cultivated in Turkey: characterization of the seed oil and essential oil. Grasas y Aceites. 2007;58(4): 359-65. Available from: https://doi.org/10.3989/gya.2007.v58.i4.447

5. Pharmacopea of the People's Republic of China. People's Medical Publishing House. Edition 1st. Vol. 1. Ovid: People's Medical Publishing House; 2005.

6. Arbizu C, Ruess H, Senalik D, Simon PW, Spooner DM. Phylogenomics of the Carrot genus (Daucus, Apiace-

ISSN 2312-0967. Pharmaceutical review. 2019. № 2 


\section{PHARMACEUTICAL BOTANYPHARMACEUTICAL BOTANY}

Фармацевтична ботаніка

Phytochemical botany

ae). American Journal of Botany. 2014;101(10): 166685. Available from: https://doi.org/10.3732/ajb.1400106

7. Pouraboli Iran, Ranjbar Banafshe / The Effect of Daucus carota Seeds Extract on Lipid Profile, LFT and Kidney Function Indicators in Streptozocin-Induced Diabetic Rats. International Journal of Plant Science and Ecology. 2015;1(3): 84-7.

8. Mahammad Shakheel B, Tripthi Saliyan, Satish S, Karunakar Hedge. Therapeutic Uses of Daucus carota: A Review. International Journal of Pharma and Chemical Research. 2017;3(2): 138-43. Available from: https:// pdfs.semanticscholar.org/527f/20adbacecdd357036c5 d069be30ee42b9f30.pdf

9. Kotova EE, Vovk OH, Kyslychenko OA, Kotov AH, Sokolova OO, Zhuravel IO. Pharmacopoeia standardiza- tion of fruits of Daucus Carota L. by macroscopic features. Theoretical and practical aspects research of medicinal plants; 3th Scientific and Practical Conference with International Participation. November 26-8; 2018. Kharkiv (Ukraine): National University of Pharmacy; 2018. p. 116-7. Available from: http://dspace.nuph.edu. ua/handle/123456789/18288. Ukrainian.

10. Gilani AH, Shaheen E, Saeed SA, Bibi S, Irfanullah, Sadiq M, et al. Hypotensive action of coumarin glycosides from Daucus carota. Phytomedicine. 2000;7(5): 423-6. Available from: https://doi.org/10.1016/S09447113(00)80064-1

11. British Herbal Pharmacopea / British Herbal Medicine Association. Bournemouth, United Kingdom, British Herbal Medicine Association; 1996.

\section{Відомості про авторів:}

Кисличенко О. А. - канд .фрарм. н., доцент, здобувач кафедри хімії природних сполук, Національний фрармацевтичний університет, Харків, Україна. e-mail: aleksandra.kyslychenko@gmail.com, ORCID 0000-0002-9667-2535

Соколова О. О. - м. н. с., Державне підприємство «Український науковий фрармакопейний центр якості лікарських засобів», Харків, Україна. е-mail: 1234osa4321@gmail.com, ORCID 0000-0002-0911-3672

Котов А. Г. - д-р. фрарм. н., профр., с. н. с., начальник відділу Державної Фармакопеї України, Державне підприємство «Український науковий фрармакопейний центр з якості лікарських засобів», Харків, Україна. e-mail: fitex16@ukr.net, ORCID 0000-0001-8893-8746

Процька В. В. - канд .фарм. н., асистент кафедри хімії природних сполук, Національний фармацевтичний університет, Харків, Україна. e-mail: vvpotskaya@gmail.com, ORCID 0000-0002-2439-138X

Журавель І. О. - д-р. фрарм. н., проф., проф. кафедри хімії природних сполук, Національний фрармацевтичний університет, Харків, Україна. e-mail: cnc@nuph.edu.ua, ORCID 0000-0002-5305-5406

Котова Е. Е. - канд. фрарм. Н., с. н. с., завідувач сектором «Експериментальна підтримка розробки монографій на ЛРС», Державне підприємство «Український науковий фармакопейний центр з якості лікарських засобів», Харків, Україна. e-mail: kotova@phukr.kharkov.ua, ORCID 0000-0003-2788-2720

\section{Information about the authors:}

Kyslychenko O. A. - PhD (Pharmacy), associate professor, doctoral student of the Department of Chemistry of Natural Compounds, National University of Pharmacy, Kharkiv, Ukraine. e-mail: aleksandra.kyslychenko@gmail.com, ORCID 00000002-9667-2535

Sokolova O. O. - Junior Research Fellowship, Ukrainian Scientific Pharmacopoeial Center for Quality of Medicines, Kharkiv, Ukraine. e-mail: 12340sa4321@gmail.com, ORCID 0000-0002-0911-3672

Kotov A. H. - DS (Pharmacy), Professor, Senior Researcher, Chief of the State Pharmacopoeia of Ukraine Department, Ukrainian Scientific Pharmacopoeial Center for Quality of Medicines, Kharkiv, Ukraine. e-mail: fitex16@ukr.net, ORCID 0000-0001-8893-8746

Protska V. V. - PhD (Pharmacy), assistant of the Department of Chemistry of Natural Compounds, National University of Pharmacy, Kharkiv, Ukraine. e-mail: vvpotskaya@gmail.com, ORCID 0000-0002-2439-138X

Zhuravel I. O. - DS (Pharmacy), Professor, Professor of the Department of Chemistry of Natural Compounds, National University of Pharmacy, Kharkiv, Ukraine. e-mail: cnc@nuph.edu.ua, ORCID 0000-0002-5305-5406

Kotova E. E. - PhD (Pharmacy), Senior Researcher, Chief of the «Experimental support for the development of monographs for medicinal plant raw materials» sector, Ukrainian Scientific Pharmacopoeial Center for Quality of Medicines, Kharkiv, Ukraine.e-mail: kotova@phukr.kharkov.ua, ORCID 0000-0003-2788-2720

ISSN 2312-0967. Фармацевтичний часопис. 2019. № 2 